\title{
BIOMARKERS AS A TOOL FOR ASSESSING DIFFUSE CONTAMINATION OF COASTAL WETLAND
}

\author{
SILVIA VILLAR $1,2,3, *$ \\ ${ }^{1}$ Sistema Nacional de Investigadores, Agencia Nacional de Investigación e Innovación (SNI. ANII), Montevideo, Uruguay \\ ${ }^{2}$ Instituto Iberoamericano de Posgrado (IBEP), España-Uruguay \\ ${ }^{3}$ Administración Nacional de Educación Pública, Montevideo, Uruguay \\ * Corresponding author: environscience21@gmail.com
}

\begin{abstract}
Playa Penino is a natural reserve located on the south coast of Uruguay. It hosts 244 species of birds (more than $50 \%$ of the bird biodiversity recorded for Uruguay). The area is included in the International BirdLife Program for biodiversity preservation. Urbanization and pollution generally have affected the quality of the water and biodiversity in wetlands. The analysis of the major wetland of Playa Penino revealed high levels of organic compounds. The biomonitoring was done using the caviomorph rodent Ctenomys pearsoni (commonly known as tuco tuco) as an indicator species because they inhabit burrows around the wetland. Genetic effects were determined using the comet assay and micronucleus test. The significant correlations between chemical and microbiological parameters and genetic damage might indicate that macronutrients from sewage could be one of the causes of the genetic damage. There is an urgent need to conserve the biodiversity of this natural area by introducing sewage treatment, cesspool control and by controlling settlement in the area etc.
\end{abstract}

Keywords: biomarkers; comet assay; Ctenomys pearsoni; micronucleus test; Playa Penino; wetland

\section{Introduction}

The net cumulative effect of humanity has been to reduce biodiversity and most societies have decreased it. The direct and indirect effects of humans on the environment are ubiquitous and almost all biodiversity research and conservation must take the possibilities of human influence into consideration (Kopnina 2016). Communities that live in the proximity of protected areas have exceeded the carrying capacity of their natural environment and are unintentionally depleting resources (Sponsel 2014).

Many wetlands harbour highly diverse biological communities and provide extensive ecosystem services. However, these important ecological features are being altered, degraded and destroyed around the world (Kopnina 2016; Sievers et al. 2017). Our current lack of knowledge of individual-level responses may therefore limit our capacity to manage wetland ecosystems effectively (Sponsel 2014; Kopnina 2016).

In South America, many wetlands are remote and far from agricultural and urban pressures. However, coastal areas have been subjected to severe anthropogenic effects (Kopnina 2016; Sievers et al. 2017). Notwithstanding their critical importance, many freshwater ecosystems are considered useless. Widespread ignorance about the important benefits that wetlands provide human societies has contributed to this notion and has promoted their destruction and degradation (Kopnina 2016; Sievers et al. 2017).

Playa Penino is a natural reserve located in the south of Uruguay. It hosts 244 species of birds (more than 50\% of bird biodiversity recorded in this country); $69 \%$ are residents and $31 \%$ are migratory species, some are vulnerable or close to threat (Arballo and Bresso 2007). It is part of the International BirdLife Program for biodiversity preservation (CFPP 2013).

Although, Aldabe et al. (2009) mention the effect of urbanization and pollution in this area, currently the landscape has been completely altered by anthropogenic activities such as; overpopulation, irregular settlements, deforestation, introduction of livestock, invasion of exotic species, sand mining and habitat fragmentation (Rocha 1999; CFPP 2013; MVOTMA 2018). Part of the livelihood of the residents is dependent on the natural resources of the Playa Penino wetlands, such as juncus, totora, shells, sand and fish (Arballo and Bresso 2007). Although local authorities declared the area a nature reserve, protected under the category of "ecological beach" and is part of the National Protected Areas System (Arballo and Bresso 2007; MVOTMA 2018), there is no effective control over the area. Under this area is the Raigón aquifer, whose depth is less than 40 meters and is the sole source of water for more than 15,000 people, including towns, industry and rural areas (Martino et al. 2008). The shallow aquifer in sandy subsoil is severely affected by wastewater discharges and the absence of a sanitary network (MVOTMA 2018). Domestic effluents empty into filtration chambers or discharged directly into ditches next to houses.

GeoUruguay report (Martino et al. 2008) indicates that the major ecological problems are erosion, mining sand for construction and loss of biodiversity due to urban expansion and pollution of natural areas. Despite its ecological importance, there are no field studies on the levels of contamination. 


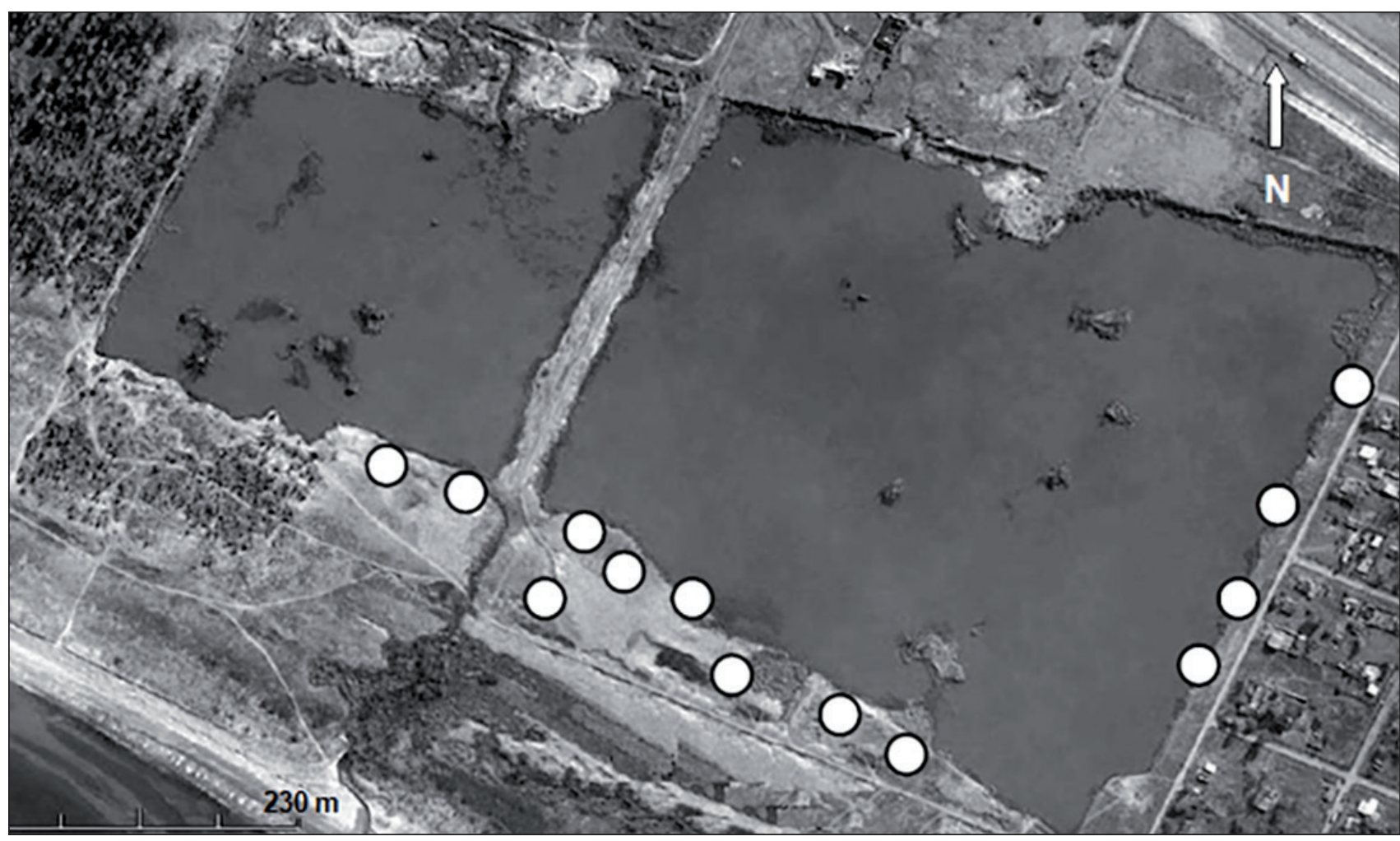

Fig. 1 Aerial photograph of the main wetland of Playa Penino with the sites, where the indicator species were captured, are indicated by the white circles. The number of circles does not represent the number of individuals captured. Modified version of the photograph in Google Earth.

A biomarker is a molecular or cellular indicator of the effects of a particular environment on the cells of an indicator species (Mudry and Carballo 2006). This makes it possible to assess the environmental conditions affect an organism. The indicator species is an organism that inhabits the ecosystem studied and has some important features. For example, it is widely distributed in the area studied and its biology is well-known, and could have a key role in the comprehension of the consequences of exposure to a xenobiotic. Identifying incipient deterioration in the indicator species indicates potential dangerous situations at sub-lethal levels, either for a point or diffuse source of a xenobiotic (Ribeiro et al. 2003; Mudry and Carballo 2006).

In environmental biomonitoring, genotoxic biomarkers are used to assess the risks to living organisms that inhabit a particular environment that is thought to be exposed to mutagenic substances (Clemente et al. 2004; Machella et al. 2006; Emmanouil et al. 2007; Yin et al. 2009; Kumar et al. 2010; Capriglione et al. 2011; Mohanty et al. 2011; Parolini et al. 2011).

The aim of this study was to determine the degree of contamination of wetland by measuring certain chemical and microbiological parameters and whether they negatively affect the site (Playa Penino) and its fauna. For the latter, we used an indicator organism, which could be affected at the molecular level by different levels of contamination: Ctenomys pearsoni (Lessa and Langguth 1983), commonly known as tuco tuco, which was chosen because they inhabit burrows around the wetland. They imbibe water in the form of raw sap from the roots of wetlands plants and rarely leave their burrows, so we do not have to consider the effects of air pollution. Genetic biomarkers of genetic damage were identified by using the comet assay and micronucleus test.

\section{Methods}

Playa Penino is a natural reserve, located in the Department of San Jose $\left(34^{\circ} 47^{\prime} \mathrm{S} 56^{\circ} 24^{\prime} \mathrm{W}\right.$; south of Uruguay). It extends for $7 \mathrm{~km}$ along the coast. The area studied is located in the wetland of Playa Penino (route 1 South, kilometer 30) (Fig. 1). Locations where the indicator animals were captured are indicated by white circles. Animals were captured using live traps. Blood was obtained without sedation by cutting the base of a rear claw. To avoid stress, each animal was placed in an opaque tube leaving only its rear end exposed. Adult individuals were selected and sexed. Following disinfection of the cut, the animals were returned to their burrows. Blood samples were collected by dripping and placed in tubes containing heparin (da Silva et al. 2000). Individuals were collected in four months of each year (February, May, August and October), which includes the widest range in seasonal variability (i.e. wet and dry months) a total of 25 females / 25 males in 2013, 23 females / 20 males in 2015 and 22 females/21 males in 2017. 


\section{Control}

Thirteen individuals (6 males and 7 female) of Ctenomys pearsoni from Playa Penino were also maintained in captivity in temperature-controlled conditions, in tanks containing sand and vegetables sufficient for a month, as negative controls. After a month, they were released back into the burrows that they previously inhabited, which were marked by flags. Blood was obtained from them during the last two days of their captivity and kept in liquid nitrogen until analysed.

\section{Genetic biomarkers}

The comet assay, or single cell gel electrophoresis (SCGE), is a standard method for determining Geno toxicity in vivo and in vitro, which records the genetic damage caused by clastogenic agents by measuring breaks in the DNA chains in specific cells (Ribeiro et al. 2003; Mudry and Carballo 2006). This characteristic and its sensitivity, makes it especially well-suited for Eco toxicological studies, both in terrestrial and aquatic environments (Ribeiro et al. 2003; Mudry and Carballo 2006; De Lapuente et al. 2015). Micronuclei are a portion or whole chromosomes that are not in the nucleus during anaphase. Their presence implies the loss of a part or an entire chromosome in daughter cells (Mudry and Carballo 2006; Luzhna et al. 2013). More than one micronucleus can be produced during cell division depending on the extent of the genetic damage (Luzhna et al. 2013).

\section{Comet assay}

The genotoxic evaluation was done using the comet assay. The standard procedure described by Hartmann et al. (2003) was used. Blood samples were centrifuged, washed in PBS and re-suspended in low melting agarose. Samples were incubated for $30 \mathrm{~min}$ at $37^{\circ} \mathrm{C}$ and slides were prepared as outlined by Hartmann et al. (2003). After incubation, $100 \mu \mathrm{l}$ of each sample was added to each slide, covered with normal agarose and subjected to lysis for $1 \mathrm{~h}$ in a lysis solution $(\mathrm{NaCl} 2.5 \mathrm{M}$, EDTA $100 \mathrm{mM}$, Tris $10 \mathrm{mM}$, Triton X100 1\% and DMSO 10\%, pH 10). The DNA was denaturalized in electrophoresis buffer for $20 \mathrm{~min}$ and after that subjected to electrophoresis for $30 \mathrm{~min}(20 \mathrm{~V}, 250 \mathrm{~mA})$. Then the slides were neutralized in Tris $0.4 \mathrm{M}$, pH 7.5 for 15 minutes and stained with propidium iodide (PI) $(10 \mu \mathrm{g} / \mathrm{ml})$. The comet visualization and measurements were done using Comet Score ${ }^{\mathrm{TM}}$ software (Tritek) and 100 cells for each individual were analysed under a fluorescence microscope (Shiner XY-FL ${ }^{\mathrm{TM}}$ ). To assess cytotoxicity, one slide was removed from lysis after 1 hour and neutralized without undergoing electrophoresis. Air dried slides were stained with PI and 100 cells per slide were scored visually. Cells were classified as normal, if their DNA was mostly condensed (normal cells) and apoptotic cells were visualized as diffused or condensed DNA without the round normal shape. Samples with a percentage of apoptosis lower than
$15 \%$ were used for this study as recommended in the protocols (Hartmann et al. 2003; Mudry and Carballo 2006).

\section{Micronucleus test}

Following the procedure described by Fenech (2007) with modifications, smears were used to determine the number of micro nucleated polychromatic erythrocytes (MN-PCE) and total percentage of micronuclei (\%o MN) in more than 2,000 cells. A micronucleus was $1 / 16$ to $1 / 3$ of the size of the main nucleus and not attached to it (Garriott et al. 2002; Norppa and Falck 2003; Zalacain et al. 2005). Frequencies were analysed using parametric and non-parametric statistics (the latter for cases, in which the conditions of normality and homoscedasticity were not met using Centurion Statgraphics XVI.I software). The observations were made under a fluorescence microscope and slides were stained with propidium iodide (PI) $(10 \mu \mathrm{g} / \mathrm{ml})$.

\section{Chemical analysis}

Water samples (one per season) were analysed in the field using the kit colour (Merckmillipore ${ }^{\mathrm{TM}}$ ) for ammonium $\left(\mathrm{NH}_{4+}\right)$ and test strips $\left(\mathrm{Hach}^{\mathrm{TM}}\right)$ for nitrates $\left(\mathrm{NO}_{3}-\mathrm{N}\right)$ and phosphates (reactive orthophosphate $\mathrm{PO}_{4}$ ) following the procedures indicated by the providers. Samples were from the surface along the shoreline of the wetland. Superficial water was collected in $500 \mathrm{ml}$ sterilized plastic bottles at five locations in the wetland. Then, they were mixed in sterilized plastic container for the analyses. Samples were obtained when the indicator animals were captured.

\section{Faecal coliform bacteria}

$3 \mathrm{M}^{\mathrm{Tm}}$ Petrifilm $^{\mathrm{Tm}}$ Enterobacteriaceae plates were used following the procedures indicated by the provider and the samples described in the chemical analysis section. Water samples were obtained along with the indicator animals using the same procedure as in the previous section.

\section{Statistical analyses}

The normality and homoscedasticity of data obtained using biomarkers of genetic damage (comet assay and $\mathrm{MN}$ test) were tested by methods based on Kolmogorov-Smirnov for normality and Levene and Tukey for homoscedasticity (Zar 2010). To compare the data on these variables, analysis of variance (ANOVA) for parametric data and Kruskal-Wallis test for nonparametric data were used. Results of all the analyses are listed in tables along with the relationships between variables analysed using multiple correlation analysis (Statgraphic Centurion XVII software). The variables that were not normally distributed were transformed prior to correlation.

\section{Agrochemical analyses}

Samples of water (obtained as already described), soil (from the burrows of the captured animals) and the 
Table 1 Values of \% damaged DNA and OTM per month/year. Control values were: $\%$ damaged DNA 5.1; OTM 0.24.

\begin{tabular}{|l|c|c|}
\hline Month $\mathbf{1}$ /ear & \% DNA damaged & OTM \\
\hline February 2013 & 31.40 & 9.08 \\
\hline May 2013 & 17.11 & 2.06 \\
\hline August 2013 & 44.97 & 7.45 \\
\hline October 2013 & 51.91 & 11.99 \\
\hline Annual average & $\mathbf{3 6 . 3 5}$ & $\mathbf{7 . 6 5}$ \\
\hline February 2015 & 34.80 & 8.78 \\
\hline May 2015 & 23.10 & 1.66 \\
\hline August 2015 & 46.00 & 7.15 \\
\hline October 2015 & 59.50 & 11.19 \\
\hline Annual average & $\mathbf{4 0 . 8 5}$ & $\mathbf{7 . 2 0}$ \\
\hline February 2017 & 33.20 & 10.21 \\
\hline May 2017 & 18.90 & 2.34 \\
\hline August 2017 & 50.14 & 8.05 \\
\hline October 2017 & 59.30 & 12.14 \\
\hline Annual average & $\mathbf{4 0 . 3 9}$ & $\mathbf{8 . 1 9}$ \\
\hline
\end{tabular}

${ }^{1}$ February corresponds to summer, May to autumn, August to winter and October to spring. This is valid for all tables.

plants they consumed were tested for the presence of agrochemicals by LATU (Laboratorio Tecnológico del Uruguay) in every season of the year 2013. Gas exchange chromatography was used for the analyses, which is accredited by the United Kingdom Accreditation Agency, UKAS. The detection limit was $1 \mathrm{ng} / \mathrm{l}$.

The presence or absence of the following pesticides was recorded: aldrin (chlorinated insecticide), carbaryl (insecticide, carbamate), cypermethrin (insecticide, pyrethroid), chlorothalonil (fungicide and chlorinated broad-spectrum insecticide), chlorpyriphos (organophosphate insecticide), dieldrin (chlorinated insecticide, prohibited use), $\alpha, \beta$ and $\lambda$ endosulfan (organochlorine insecticide and acaricide, prohibited), malathion (organophosphate insecticide), methylchlorpyriphos (insecticide, organophosphate), methyl parathion (organophosphate, prohibited) (insecticide, pyrethroid), procymidone (chlorinated fungicide).

\section{Results}

Average values for the percentage of DNA damaged (\% DNA damaged) and Olive tail moment (OTM) in the lymphocytes of Ctenomys did not differ between males and females (Table 1), Mann-Whitney U test $(\mathrm{p}=0.08)$.

Data provided is for all the individuals sampled. Both variables are normally distributed according to Kolmogorov-Smirnov and homoscedastic according to Levene and Tukey tests. ANOVAs show highly significant differences $(p<0.01)$ between samples in all months in each year in both variables and the control samples, and no
Table 2 Values of PCE-MN and \%o MN per month/year. *Significantly different from the other months. Control values were: MN-PCEs 0.03; \%o MN 0.04.

\begin{tabular}{|l|c|c|}
\hline Month/Year & MN-PCEs & \%o MN \\
\hline February 2013 & 2.4 & 2.8 \\
\hline May 2013 & 1.5 & 1.7 \\
\hline August 2013 & 2.0 & 2.6 \\
\hline October 2013 & $5.6^{*}$ & $5.9^{*}$ \\
\hline Annual average & $\mathbf{2 . 9}$ & $\mathbf{3 . 3}$ \\
\hline February 2015 & 2.3 & 3.2 \\
\hline May 2015 & 1.6 & 1.8 \\
\hline August 2015 & 2.1 & 2.7 \\
\hline October 2015 & $5.7^{*}$ & $6.2^{*}$ \\
\hline Annual average & $\mathbf{3 . 0}$ & $\mathbf{3 . 5}$ \\
\hline February 2017 & 2.2 & 2.6 \\
\hline May 2017 & 1.6 & 1.8 \\
\hline August 2017 & 2.1 & 2.5 \\
\hline October 2017 & $5.3^{*}$ & $5.5^{*}$ \\
\hline Annual average & $\mathbf{2 . 8}$ & $\mathbf{3 . 1}$ \\
\hline
\end{tabular}

significant differences between the annual values for the three years $(\mathrm{p}<0.05)$.

In Table 2, values for polychromatic erythrocytes (PCE) with one or more micronuclei (MN-PCEs) and $\%$ MN are shown. There are no significant differences between males and females according to Mann-Whitney $\mathrm{U}$ test $(\mathrm{p}=0.075)$. Data provided is for all the total individuals sampled. The MN-PCEs counted were 2000 (2 smears per individual) and values were averaged. Only polychromatic erythrocytes were counted as the spleen of Ctenomys removes abnormal erythrocytes from its blood, therefore normochromatic erythrocytes (NCE) were not detected. According the Kruskal-Wallis tests, there are significant differences $(\mathrm{p}<0.05)$ between the October samples for each year and the other months analysed for both variables (MN-PCEs and \%o MN). All samples showed significant differences relative to the controls $(p<0.05)$. There were no significant differences between the annual values of the three years $(\mathrm{p}<0.05)$.

Phosphate reached its highest values in May and February in each year and nitrates increased in May only in 2013. Values for ammonium, on the other hand, were lowest in May and high in the February and October samples, which is coincident with the increase in the ammonium values. Faecal coliform bacteria (FC) also showed an increase in the months of February and October in each year (Table 3 ).

FC concentration was positively and significantly correlated with OTM. The concentration of ammonia was positively correlated $(\mathrm{p}<0.05)$ with the biomarkers of genotoxicity (\% damaged DNA and OTM). The percentage FC correlates positively and significantly with the concentration of ammonia in water $(0.985$, data not 
Table 3 Values of the chemical and microbiological parameters of the compound samples from the wetland for each month/year.

\begin{tabular}{|l|c|l|c|c|}
\hline Month/Year & $\begin{array}{c}\text { Phosphates } \\
\text { (mg/l) }\end{array}$ & $\begin{array}{c}\text { Nitrates } \\
\text { (mg/l) }\end{array}$ & $\begin{array}{c}\text { Ammonium } \\
\text { (mg/l) }\end{array}$ & $\begin{array}{c}\text { Faecal } \\
\text { coliform } \\
\text { bacteria } \\
\text { (CFU/100 } \mathbf{~} \mathbf{l})\end{array}$ \\
\hline February 2013 & 1.0 & 0 & 1.0 & 1300 \\
\hline May 2013 & 1.0 & 0.15 & 0 & 300 \\
\hline August 2013 & 0 & 0 & 0 & 800 \\
\hline October 2013 & 0 & 0 & 1.0 & 1500 \\
\hline Annual average & $\mathbf{0 . 5}$ & $\mathbf{0 . 0 0 4}$ & $\mathbf{0 . 5}$ & $\mathbf{9 7 5}$ \\
\hline February 2015 & 1.0 & 0.15 & 1.0 & 1300 \\
\hline May 2015 & 0.5 & 0.15 & 0.5 & 300 \\
\hline August 2015 & 0 & 0 & 0 & 800 \\
\hline October 2015 & 0 & 0 & 1.0 & 1700 \\
\hline Annual average & $\mathbf{0 . 4}$ & $\mathbf{0 . 0 8}$ & $\mathbf{0 . 6}$ & $\mathbf{1 0 2 5}$ \\
\hline February 2017 & 1.0 & 0.15 & 1.0 & 1200 \\
\hline May 2017 & 0.5 & 0.3 & 0 & 300 \\
\hline August 2017 & 0 & 0 & 0.5 & 700 \\
\hline October 2017 & 0 & 0 & 1.0 & 1600 \\
\hline Annual average & $\mathbf{0 . 4}$ & $\mathbf{0 . 1 1}$ & $\mathbf{0 . 6}$ & $\mathbf{9 5 0}$ \\
\hline
\end{tabular}

shown in the Table). Correlation coefficient between phosphates and \%o MN was moderate (Table 4).

There were no agrochemicals present in the water, soil and plants in any season of the year when they were recorded.

\section{Discussion}

\section{Genetic damage}

The biomarkers used revealed higher levels of genetic damage compared to other studies using the same genus (Ctenomys). The percentages of MN-PCEs and \%o MN reveal the existence of serious genetic damage in the indicator species. The MN-PCEs values exceed those reported by Heuser et al. (2002) in Ctenomys minutus exposed to elevated levels of hydrocarbons and heavy metals $(\mathrm{MN}$ PCEs value $=0.76$ ) at locations along route 30 (coast of Rio Grande do Sul, Brazil). They are also higher than the maximum values of MN-PCEs (value $=2.8$ ) obtained by da Silva et al. (2000) in Ctenomys torquatus for individuals exposed to polycyclic aromatic hydrocarbons (PAHs)

Table 4 Multiple correlation test showing significant coefficients at $p<0.05$. NS $=$ not significant.

\begin{tabular}{|l|c|c|c|c|}
\hline \multicolumn{2}{|l|}{ Correlation coefficients $\mathrm{p}<0.05$} \\
\hline & Phosphates & Nitrates & Ammonium & $\begin{array}{c}\text { Faecal } \\
\text { coliforms }\end{array}$ \\
\hline$\%$ damaged DNA & NS & NS & 0.980 & NS \\
\hline OMT & NS & NS & 0.969 & 0.975 \\
\hline PCE-MN & NS & NS & NS & NS \\
\hline$\% \circ$ MN & NS & 0.531 & NS & NS \\
\hline
\end{tabular}

in a coal mining area located at Candiota in southern Brazil. The values of MN-PCEs also are higher than the maximum value obtained by Ayla et al. (2005) for rats exposed to lead acetate (a solvent used in the production of cosmetics and furniture) (value $=2.41$ ).

The average \% of DNA damaged ranged from 36 to $41 \%$. Kopjar et al. (2008) report values of $0.85-7.37$ for $\%$ DNA damaged and 0.11-0.86 for OTM, in peripheral blood of fish from rivers that were contaminated with urban effluents (nitrates, nitrites, and ammonium). Festa et al. (2003) report maximum values for $\%$ of DNA damaged of 32.8 and Tail Moment of 38.28 in Mus spretus blood cells during a toxic spill at the Aznalcollar mine in Doñana National Park, which dumped acidic water, mud full of toxic metals and arsenic into the Guadiamar River.

The highest values recorded in this study indicate the presence of the genotoxic agents lead, hydrocarbons, heavy metals and arsenic in the Playa Penino wetland. It is likely that these xenobiotics are entering the blood system of the indicator species via the plants it consumes.

\section{Effects of the chemicals and bacteria}

There were no registered agrochemicals in the samples of water, soil and plants analysed. Although antibiotics were not tested for in the water, it is important to point out that Rodríguez (2010) reports values for these substances of less than $1 \mu \mathrm{g} / \mathrm{l}$ in surface waters in areas with larger populations than at Playa Penino. This value is the minimum that results in adverse effects on microorganisms in vitro (Rodríguez 2010). Moreover, the concentration of microorganisms should be affected by the presence of antibiotics in the water, so that the high concentrations of enterobacteria recorded in this study is not consistent with the presence of toxic levels of antibiotics (Rodríguez 2010).

Even though the presence of detergents was not recorded, many of them include phosphate, which would generate a very big increase in the phosphate values of water samples (Romero 2006).

According to ordinance 253/79 governing the quality of water in Uruguay (MVOTMA 1979), the Playa Penino wetland corresponds to class $2 \mathrm{~b}$, which includes "waters intended for recreation by direct contact with the human body for many residents and visitors of the area" or class 3 "waters destined to the preservation of fish in general and other members of the water flora and fauna, or also waters destined to the irrigation of crops whose product is not consumed in a natural way or in those cases that being consumed in natural way irrigation systems are applied that do not cause the product to wet". For either class, the value for ammonia exceeded the allowable limits in all samples (allowable limit $0.02 \mathrm{mg} / \mathrm{l}$ ). In contrast, nitrates are below the limits set by this ordinance $(10 \mathrm{mg} / \mathrm{l})$.

Regarding the nitrogen-related contributions, the average annual values ranged from 0.5 to $0.6 \mathrm{mg} / \mathrm{l}$ for ammonium. For nitrates, the average annual values ranged from 0.004 to $0.11 \mathrm{mg} / \mathrm{l}$. The average annual nitrate val- 
ues and their maximum values $(0.11 \mathrm{mg} \mathrm{NO} / \mathrm{l})$ were below the national and international standards (Arocena et al. 2008). The maximum average ammonium values $\left(0.6 \mathrm{mg} \mathrm{NH}_{4} / \mathrm{l}\right)$ exceeded not only these ranges, but the international values for the preservation of aquatic life and drinking water (Arocena et al. 2008). Ammonia is not toxic, but its presence even in low concentrations may mean the presence of faecal bacteria and pathogenic microorganisms in the water. Ammonia is produced during the first inorganic stage of the bacterial breakdown of urea and proteins, and it is a good indirect chemical indicator of the faecal contamination of water (Laws 1993; Rodríguez et al. 2006).

The average values for phosphate $\left(\mathrm{PO}_{4}\right)$ ranged from 0.4 to $0.5 / \mathrm{l}$, which is greater than the internationally recommended level (Delgadillo et al. 2010; Putz 2010). Phosphates are directly related to the eutrophication of rivers, and especially lakes and reservoirs, considering that only one gram of phosphate $\left(\mathrm{PO}_{4}\right)$ causes the growth of up to $100 \mathrm{~g}$ of algae (Delgadillo et al. 2010; Putz 2010). Directive UE 91/271/EEC indicates that the critical concentrations for incipient eutrophication are between $0.1-0.2 \mathrm{mg} / \mathrm{PO}_{4}$ in running water and between 0.005-0.01 mg/l $\mathrm{PO}_{4}$ in still water (De Azevedo and $\mathrm{Da}$ Matta 2004; Márquez et al. 2007; Putz 2010).

Phosphorus, unlike nitrogen, is not obtained from the atmosphere; it comes from the excreta of living organisms and is mainly contained in fertilizers, pesticides, detergents and sewage (Márquez et al. 2007). Rainfall is higher from January to May than in other months $(110 \mathrm{~mm} /$ month $)$ in the San José Department (climate-data.org), which may account for the higher levels of phosphate in water being a product of runoff and filtration from rudimentary septic chambers.

Nitrogen and phosphorus are essential for all living organisms, as they are a basic part of molecules such as proteins and nucleic acids (Spiro and Stigliani 2004), and play a key role in their growth. Under normal conditions, these substances come mainly from external natural contributions and the decomposition of dead organic matter (recycling). When the environmental conditions are altered, however, the additional contributions come mostly from the discharge of urban waste and certain industrial processes, as well as from the increasing use of fertilisers and pesticides in agriculture (De Azevedo and Da Matta 2004; Spiro and Stigliani 2004; Cicerone et al. 2007).

In urban or domestic wastewater effluents, nitrogen is present primarily as organic nitrogen or ammonium and, to a lesser extent, as nitrites and nitrates (De Azevedo and Da Matta 2004; Spiro and Stigliani 2004; Cicerone et al. 2007; Delgadillo et al. 2010). The reduced nitrogen is converted into nitrite (nitrification) and subsequently into nitrate (De Azevedo and Da Matta 2004; Cicerone et al. 2007; Newman and Clements 2008; Delgadillo et al. 2010).

Ammonium particularly inhibits the symbiotic fixation of nitrogen by microorganisms associated with plants, which are in close contact with water in the wetland environment (Newman and Clements 2008; Delgadillo et al. 2010). This process is indirectly affected by the increase in the cytoplasmic concentration of ammonium in the roots exceeding their assimilative capacity (Newman and Clements 2008; Delgadillo et al. 2010). The chemical compounds detected in the wetland at Playa Penino might be affecting the genome of the indicator species, which lives in burrows, in the immediate proximity of water, consumes the roots of the vegetation associated with the wetland, absorbing the sap and pollutants present especially in those species with a high water content (Equisetum sp., Cynodon dactylon and Paspalum nicorae).

In an aquatic environment, the presence of nitrogen in the form of ammonia is regulated by a chemical equilibrium that determines the coexistence of two forms: ammonia $\left(\mathrm{NH}_{3}\right)$ and ammonium ions $\left(\mathrm{NH}_{4}{ }^{+}\right)$. The relative proportion of each is determined by $\mathrm{pH}$, temperature and ionic strength (Delgadillo et al. 2010). The concentration of ammonia increases with increase in $\mathrm{pH}$ and temperature and decreases with increase in ionic strength; the ammonium ion predominates at $\mathrm{pH}$ values lower than 7 (Pepe and Lombardi 2003). The toxicity of ammonia for organisms is related to the non-ionized form (ammonia), mainly because it is highly soluble in lipids, which facilitates its passage through biological membranes, causing damage to respiratory surfaces. In fish, for example, the distal parts of the fins lose their original colour and turn white or transparent (Pepe and Lombardi 2003; Spiro and Stigliani 2004). Ammonium salts induce skin secretions and destroy gills (Pepe and Lombardi 2003; Spiro and Stigliani 2004). Relevant to this, the mass death of fish recorded in 2013 and 2015 in Playa Penino could have resulted from the process described above.

In the digestive system of mammals, nitrogen compounds (ammonium and nitrates) are transformed into nitrites by microbes. An excess of nitrite induces the formation of methaemoglobin (Khademikia et al. 2013), which blocks haemoglobin transporting oxygen. In addition, these nitrogen compounds (nitrates and nitrites) in water can be transformed into nitrosamines, whose teratogenic and carcinogenic potential is recognized (Camargo and Alonso 2006). As mentioned before, tuco tuco obtains water from the roots of the plants (raw sap, mostly from grass in this area), so they may be accumulating these compounds, as they are in the water and their metabolic transformation could occur later, in other parts of the plants. However, this needs to be tested under controlled conditions in the laboratory.

The ability of faecal bacteria to reproduce outside the intestine of mammals is favoured by suitable environmental conditions (Eaton and Franson 2005). Their presence is interpreted as an indication that pathogenic organisms may be present and their absence that the water or food is free of disease-producing organisms (Eaton and Franson 2005). Uruguayan ordinance 253/79 
(MVOTMA 1979) establishes a maximum limit of $1000 \mathrm{cfu} / 100 \mathrm{ml}$ for faecal coliform bacteria (FC) for class 3 water and a maximum limit of $500-1000 \mathrm{cfu} / 100 \mathrm{ml}$ for class 2 water. The microbiological contamination by FC recorded in this study exceeded the guide levels for these classes of water, as well as for drinking water (according to national and international regulations) and are a risk even for the recreational use of water (Delgadillo et al. 2010). The values of FC recorded in this study were similar (May) or higher (October and February) to those recorded in sections of the Traiguén IX Region river in Chile (540 cfu/ml; $1100 \mathrm{cfu} / \mathrm{ml} ; 920 \mathrm{cfu} / \mathrm{ml}$ ) (Rivera et al. 2009). Pérez et al. (2004) report FC values for the water in Lake Izabal and Río Dulce, in Guatemala, which are lower than those recorded in this study (Lake Izabal $454 \mathrm{cfu} / 100 \mathrm{ml}$ and Río Dulce $62 \mathrm{cfu} / 100 \mathrm{ml}$ ). These authors mention that these levels of contamination pose a health hazard for the population inhabiting the margins of these environments. Something similar occurs in the Playa Penino wetland, which is also used for irrigation, fishing and recreational uses by the surrounding population.

Pollution by both bacteria and chemicals pose a high risk to human health, affect the crops and reduce the availability and quality of fish, which are a source of food for communities where the incidence of poverty is high.

The multiple correlation analysis (MCA) revealed significant positive correlations between the concentration of ammonia and the presence of enterobacteria, and the genetic damage recorded in the blood cells of Ctenomys. Although positive these relationships do not prove there is causal connection between the genetic and environmental variables. It might indicate that the discharge of sewage has a negative effect on the wetland. This requires additional in vivo and in vitro studies.

Squatter settlements around Playa Penino along with the lack of an urban sanitation system has resulted in an increase in nutrients to above the maximum allowed by current national and international regulations, which has disturbed natural nutrient cycling.

\section{Conservation implications}

The results of this study might indicate the decrease in biodiversity at Playa Penino is due to an acute and chronic exposure of the genetic material of the organisms there to pollutants that in the long-term might reduce their fitness and survival.

An indicator species was used to detect a potentially dangerous situation associated with the presence and action of pollutants, which to some extent can be extrapolated to humans (Alonso and Tabor 2004; Den Besten and Munawar 2005; Bischoff et al. 2010; Fernández-Tajes et al. 2011). The extent of the genetic damage to individual cells measured using OTM and percentage of DNA damaged revealed acute and recent exposure to xenobiotics, which may be associated with the discharge of domestic wastewater. The MN test also revealed the chronic exposure of the animals showing genetic damage to clastogenic and/or aneugenic events (Mudry and Carballo 2006).

It is essential to maintain the ecosystem integrity of Playa Penino and ensure the protection of the health ofhumans by a strict surveillance and control of septic tanks and design of an adequate sanitation system. The regularization of the squatter settlements through a housing plan that contemplates the socio-economic possibilities of the inhabitants, would reduce the pollutant load from sewage.

The restoration of the physical-chemical balances between the soil, water and sediment will also be beneficial, as is described in the GeoUruguay report (Martino et al. 2008).

\section{REFERENCES}

Aldabe J, Mejía P, Morena V (2009) Propuesta de proyecto de selección y delimitación del área Humedales del Santa Lucía para su ingreso al Sistema Nacional de Áreas Protegidas. MVOTMA. Uruguay.

Alonso A, Tabor G (2004) Special Section: Marine Sentinel Species. Introduction: Marine Vertebrates as Sentinels of Marine Ecosystem Health. Eco Health 1: 236-238.

Arballo E, Bresso A (2007) Reserva Natural Playa Penino. Fondo de las Américas, Intendencia Municipal de San José, DINAMA. Uruguay.

Arocena R, Chalar G, Fabián D, de León L, Brugnoli E, Silva M, Rodó E, Machado I, Pacheco J, Castigioni R, Gabito L (2008) Evaluación ecológica de aguas y biomonitoreo. DINAMA. Uruguay.

Ayla C, Oya O, Ulkü C (2005) The evaluation of micronucleus frequency by acridine orange fluorescent staining in peripheral blood of rats treated with lead acetate. Mutagenesis 20: 411-415.

Bischoff K, Priest H, Mount-Long A (2010) Animals as Sentinels for Human Lead Exposure: A Case Report. J Med Toxicol 6: 185-189.

Camargo J, Alonso A (2006) Ecological and toxicological effects of inorganic nitrogen pollution in aquatic ecosystems: A global assessment. Environ Int 32: 831-849.

Capriglione T, De Iorio S, Gay F, Capaldo A, Vaccaro M, Morescalchi M, Laforgia V (2011) Genotoxic effects of the fungicide ethiophanate-methylon Podarcis sicula assessed by micronucleus test, comet assay and chromosome analysis. Ecotoxicology 20: 885-891.

Cicerone D, Sánchez-Proaño P, Reich S (2007) Contaminación y medioambiente. Eudeba, Argentina.

Clemente B, Devaux A, Perrodin Y, Danjean M, Ghidini-fatus M (2004) Assessment of sediment ecotoxicity and genotoxicity in freshwater laboratory microcosms. Ecotoxicology 12: 323-333.

Comisión de Fomento Playa Penino (CFPP) (2013) Reserva Natural Playa Penino. Proyecto de Gestión Ambiental: Pobladores de Autódromo y Penino unidos en la restauración y recuperación ambiental de la faja costera aledaña a la Playa, como medida de mitigación y adaptación al Cambio Climático. MVOTMA/ PPD/FMAM/PNUD, Uruguay.

da Silva J; Freitas T; Heuser V; Marinho J, Erdtmann B (2000) Genotoxicity biomonitoring in coal regions using wild rodent Ctenomys torquatus by comet assay and micronucleus test. Environ Mol Mutag 35: 270-278. 
De Azevedo F, Da Matta A (2004) As bases toxicológicas da ecotoxicologia. Intertox. RIMA. Brasil.

De Lapuente J, Lourenço J, Mendo Sónia A, Borràs M, Martins M, Costa P, Pacheco M (2015) The Comet Assay and its applications in the field of ecotoxicology: a mature tool that continues to expand its perspectives. Front Genet 6: 180.

Delgadillo O, Camacho A, Pérez L, Andrade M (2010) Depuración de aguas residuales por medio de humedales artificiales. In: Durán N (ed) Centro Andino para la Gestión y Uso del Agua (Centro AGUA). Universidad Mayor de San Simón, Bolivia.

Den Besten J, Munawar M (2005) Ecotoxicological testing of marine and freshwater ecosystems: emerging techniques, trends, and strategies. CRC Press, Taylor and Francis Group.

Eaton A, Franson M (2005) Standard methods for the examination of water and wastewater. American Public Health Association.

Emmanouil C, Sheehan T, Chipmana J (2007) Macromolecule oxidation and DNA repair in mussel (Mytilus edulis L.) gill following exposure to $\mathrm{Cd}$ and $\mathrm{Cr}(\mathrm{VI})$. Aquat Toxicol 82: 27-35.

Fenech M (2007) Cytokinesis-block micronucleus cytome assay. Nat Protoc 2: 1084-1104.

Fernández-Tajes J, Flórez F, Pereira S, Rábade T, Laffon B, Méndez J (2011). Use of three bivalve species for biomonitoring a polluted estuarine environment. Environ Monit Assess 177: 289-300.

Festa F, Cristaldi M, Ieradi L, Moreno S, Cozzi R (2003) The comet assay for the detection of DNA damage in Mus spretus from Doñana National Park. Environ Res 91: 54-61.

Garriott M, Phelps J, Hoffman W (2002) A protocol for the in vitro micronucleus test. I. Contributions to the development of a protocol suitable for regulatory submissions from an examination of 16 chemicals with different mechanisms of action and different levels of activity. Mutat Res 517: 123-134.

Hartmann A, Agurell E, Beevers C, Brendler-Schwaab S, Burlinson B, Clay P, Collins A, Smith A, Speit G, Thybaud B, Tice R (2003) Recommendations for conducting the in vivo alkaline Comet assay. Mutagenesis 18: 45-51.

Heuser V, da Silva J, Moriske H, Dias J, Yoneama M, Freitas T (2002) Genotoxicity biomonitoring in regions exposed to vehicle emissions using the comet assay and the micronucleus test in native rodent Ctenomys minutus. Environ Mol Mutag 40: 227-235.

Khademikia S, Rafiee Z, Amin M, Poursafa P, Mansourian M, Modaberi A (2013) Association of nitrate, nitrite, and total organic carbon (TOC) in drinking water and gastrointestinal disease. J Environ Public Health, https://www.doi .org/10.1155/2013/603468.

Kopnina, N (2016) Forest Ecosystem Services Commodification of natural resources and forest ecosystem services: examining implications for forest protection. Environ Conserv, https://www .doi.org/10.1017/S0376892916000436.

Kopjar N, Mustafic P, Zanella D, Buj I, Caleta M, Marcic Z, Milic M, Zdravko D, Mrakovcic M (2008) Assessment of DNA integrity in erythrocytes of Cobitis elongate affected by water pollution: the alkaline comet assay study. Folia Zool 57: 120-130.

Kumar R, Nagpure N, Kushwaha B, Srivastava S, Lakra W (2010) Investigation of the genotoxicity of malathion to freshwater teleost fish Channa punctatus (Bloch), using the micronucleus test and comet assay. Arch Environ Contam Toxicol 58: 123-130.

Laws E (1993) Aquatic pollution: an introductory text. John Wiley, New York.

Lessa EP, Langguth A (1983) Ctenomys pearsoni n. sp. (Rodentia, Octodontidae) del Uruguay. Res. Comun. Jorn. Cienc. Nat 3: 86-88.
Luzhna L, Kathiria P; Kovalchuk O (2013) Micronuclei in genotoxicity assessment: from genetics to epigenetics and beyond. Front Genet 4: 131.

Machella N, Battino M, Pisanelli B, Regoli F (2006) Influence of the SCGE Protocol on the Amount of Basal DNA Damage Detected in the Mediterranean Mussel, Mytilus galloprovincialis. Environ Mol Mutagen 47: 579-586.

Márquez A, Senior W, Martínez G, González A (2007) Concentraciones de nitrógeno y fósforo en sedimentos recientes de la Laguna Los Patos, Estado Sucre, Venezuela. Bol Inst Oceanogr 46: 137-145.

Martino D, Buonomo M, Villalba C (2008) GeoUruguay: Informe del estado del ambiente. CLAES, PNUMA, DINAMA. Uruguay.

Ministerio de Vivienda, Ordenamiento Territorial y Medioambiente (MVOTMA) (2018) Plan de aguas urbanas, Ciudad del Plata, Uruguay.

Mohanty G, Mohanty J, Nayak A, Mohanty S, Dutta S (2011) Application of comet assay in the study of DNA damage and recovery in rohu (Labeo rohita) fingerlings after an exposure to phorate an organophosphate pesticide. Ecotoxicology 20: 283-292.

Mudry M, Carballo M (2006) Genética Toxicológica. Ed. De los 4 Vientos. Argentina.

MVOTMA (1979) Código de aguas. www.mvotma.gub.uy/decretos-ministerio/item/10010048-decreto-253-979.

Newman MC, Clements WH (2008) Ecotoxicology: a comprehensive treatment. CRC Press, Taylor and Francis Group, Boca Raton, London and New York.

Norppa H, Falck G (2003) What do human micronuclei contain? Mutagenesis. 18: 221-233.

Parolini M, Binelli A, Provini A (2011) Assessment of the potential cyto-genotoxicity of the nonsteroidal antiinflammatory drug (NSAID) diclofenac on the zebra mussel (Dreissena polymorpha). Water Air Soil Pollut 217: 589-601.

Pepe U, Lombardi M (2003) Tratamiento alternativo de efluentes cloacales individuales. $13^{\circ}$ Congreso Argentino de saneamiento y medioambiente. Buenos Aires.

Pérez F, Oliva B, Herrera K, Juárez J, Galindo C (2004) Contaminación físicoquímica y bacteriológica del Río Dulce y lago de Izabal. Final report, Proj. DIGI-USAC, Guatemala.

Putz P (2010) Eliminación y determinación del fosfato. Hach Lange www.interempresas.net/Quimica.

Ribeiro L, Salvadori D, Marques E (2003) Mutagenese Ambiental. Ed. ULBRA. Brasil.

Rivera N, Encina F, Palma R, Mejías P (2009) La Calidad de las Aguas en el Curso Superior y Medio del Río Traiguén. IX Región-Chile. Información Tecnológica 20: 75-84.

Rocha G (1999) Playa Penino y la conservación de los hábitats costeros del Uruguay. Cotinga 11: 68-70.

Rodríguez R (2010). Influencia de los fármacos presentes en el agua residual sobre la resistencia de la bacteria Escherichia coli y su eliminación por oxidación avanzada. PhD Thesis, CONACYT, México.

Rodríguez A, Arpajón Y, Castaño Z, Marsán R, Lugo D, Roevros N, Chou L, Rojas N, Heydrich M (2006) Análisis de contaminantes inorgánicos tóxicos en las aguas del río Almendares, Cuba. ENMA, CONYMA.

Romero R (2006) Detergentes con o sin fosfatos. Técnica Industrial, España.

Sievers M, Hale R, Parris K, Swearer S (2017) Impacts of human induced environmental change in wetlands on aquatic animals. Biol Rev, https://www.doi.org/10.1111/brv.12358.

Spiro T, Stigliani W (2004) Química medioambiental. Pearson-Prentice HallPearson, Madrid. 
Sponsel L (2014) Human impact on biodiversity: overview. In Levin SA, Waltham MA (eds) Encyclopedia of Biodiversity. Academic Press. pp 137-152.

Yin X, Zhu G, Li X, Liu S (2009) Genotoxicity evaluation of chlorpyrifos to amphibian Chinese toad (Amphibian: Anura) by Come assay and Micronucleus test. Mutat Res-Gen Tox En 680: 2-6.
Zalacain M, Sierrasesúmaga L, Patiño A (2005) El ensayo de micronúcleos como medida de inestabilidad genética inducida por agentes genotóxicos. Revisión 28, https://www.doi.org/10.4321 /S1137-66272005000300007.

Zar J (2010) Biostatistical Analysis. Pearson Education. London. 